ISSN: $2317-8957$

Volume 6, Number 1, Jun. 2018

\title{
INFLUENCE OF REACTION TIME AND CARBON DISULFIDE AMOUNT ON SULFOPHOSPHORYLATION REACTION OF PHOSPHORYLATED RESINS
}

\author{
MARCELO AUGUSTO VIEIRA SOUZA ${ }^{1}$, LUIZ CLAUDIO SANTA MARIA ${ }^{1}$, LUCIANA DA CUNHA \\ COSTA $^{2}$, MARCOS ANTONIO DA SILVA COSTA ${ }^{1}$, FABIO MERÇON $^{1}$
}

${ }^{1}$ Universidade do Estado do Rio de Janeiro, Rio de Janeiro, RJ, Brasil.
${ }^{2}$ Fundação Centro Universitário Estadual da Zona Oeste, Rio de Janeiro, RJ, Brasil.

\section{RESUMO}

Neste trabalho, estudamos a reação de sulfofosforilação de resinas fosforiladas variando o tempo de reação e a quantidade de CS2 e caracterizando estes materiais por termogravimetria (TG) e espectroscopia no infravermelho (FTIR). A estabilidade térmica e os espectros de FTIR dos copolímeros de Sty-DVB foram significativamente alterados após as reações de fosforilação e sulfofosforilação. Os copolímeros não modificados apresentaram um estágio de degradação enquanto os copolímeros sulfofosforilados apresentaram dois estágios de degradação, devido à presença de fósforo e enxofre na matriz polimérica. Houve uma tendência ao aumento do teor de grupos sulfofosforilo incorporados nos copolímeros de Sty-DVB com o aumento da quantidade de CS2 e do tempo de reação. No entanto, para quantidades elevadas de CS2, não foi necessário um longo tempo de reação para transformar os grupos fosforilo em grupos sulfofosforilo. O melhor grau de conversão dos grupos fosforil em sulfofosforilo foi obtido pelo tempo de reação de 144 he 0,25 mol de CS2.

Palavras-chave: Sulfofosforilação, Sty-DVB, FTIR.

\begin{abstract}
In this work, we studied the sulfophosphorylation reaction of phosphorylated resins by varying the reaction time and CS2 amount and characterized these materials thoroughly by thermogravimetry (TG) and infrared spectroscopy (FTIR). The thermal stability and the FTIR spectra of the StyDVB copolymers were significantly changed after the phosphorylation and sulfophosphorylation reactions. The unmodified copolymers presented one degradation stage while the sulfophosphorylated copolymers showed two degradation stages, due to the presence of phosphorous and sulfur in the polymeric matrix. There was a tendency for increasing content of sulfophosphoryl groups incorporated into the Sty-DVB copolymers with increasing CS2 amount and reaction time. However, for high CS2 amounts, a long reaction time was not necessary to transform the phosphoryl groups into sulfophosphoryl groups. The best conversion degree of phosphoryl into sulfophosphoryl groups was obtained by using reaction time of $144 \mathrm{~h}$ and $0.25 \mathrm{~mol}$ of CS2.
\end{abstract}

keywords: Sulfophosphorylation, Sty-DVB, FTIR.

\section{1) INTRODUCTION}

Organophosphorus and complex sulfur compounds have been reported to possess biocidal action ${ }^{1,2}$. The sulfur and phosphorus atoms of these compounds interact with positivity charged sites of the lipoproteins present in the bacterial cell wall, probably leading to protein denaturation ${ }^{3}$. Biocidal functional groups can be immobilized in polymer matrices. The immobilization of functional groups in polymer matrices is widely used, since chemical modification can be made in various types of polymer supports, through several synthetic routes ${ }^{4}$. 
Association of sulfur and phosphorous atoms in sulfophosphoryl groups confers biocidal properties to these innovative materials ${ }^{3}$. The phosphorylation reaction of styrene-divinylbenzene (Sty-DVB) copolymers has been studied in our previous work and the synthesized materials have been characterized ${ }^{5}$.

In another our previous work has been reported the introduction of sulfophosphoryl groups into Sty-DVB copolymers ${ }^{3}$. Reaction of phosphoryl groups with $\mathrm{CS}_{2}$ in order to introduce sulfophosphoryl groups into Sty-DVB copolymers was difficult to achieve, with low conversion degree ${ }^{3}$. This reaction was based on reaction of conversion of amino acid into dithiocarbamate groups ${ }^{6}$, although they are different reactions. The sulfophosphorylated copolymers presented excellent biocidal activity, but the reaction proved to be extremely slow. In addition, the literature does not report the detailed study of the conversion reaction of phosphoryl into sulfophosphoryl groups and the broad characterization of the synthesized materials. The reaction time and the amount of carbon disulfide used in the sulfophosphorylation reaction are important reaction parameters. These parameters influence the sulfophosphorylation degree. Apart from being a chemical modification reaction in heterogenous phase, not described in the literature, since the reaction occurs in a crosslinked polymeric structure, therefore insoluble, the study has unpublished results regarding sulfophosphorylation reaction by varying and optimizing these parameters, which makes the work be inovative and relevant. Thus, the aim of this work was study widely the influence of these parameters in the sulfophosphorylation reaction and determine the optimum parameters for this reaction.

\section{2) EXPERIMENTAL}

2.1 Introduction of sulfophosphoryl groups into Sty-DVB copolymer

The Sty-DVB copolymer of high porosity prepared by suspension polymerization by free radical was submitted to phosphorylation reaction with $\mathrm{PCl}_{3}$ by varying the molar ratio $\mathrm{PCl}_{3}: \mathrm{AlCl}_{3}$ and the reaction temperature (Table 1) according to the method previously published ${ }^{5}$. The sulfophosphorylation reaction was carried out in a $100 \mathrm{~mL}$ reactor equipped with mechanical stirring by employing $0.25 \mathrm{~g}$ of phosphorylated Sty-DVB copolymer, a solution of $15 \mathrm{~mL} \mathrm{NaOH} 1 \mathrm{M}$ in ethanol and different amounts of $\mathrm{CS}_{2}$ (Table 2). The reaction was maintained at $25^{\circ} \mathrm{C}$ for varied time periods (Table 2). After the reaction, the beads were washed several times with hot water until neutral $\mathrm{pH}$, extracted with $100 \mathrm{~mL}$ acetone under reflux for $24 \mathrm{~h}$ in a Soxhlet apparatus and dried in an oven at $60{ }^{\circ} \mathrm{C}$ for $24 \mathrm{~h}^{3}$.

\subsection{Characterizations}

Thermal analyses of the copolymers were conducted with a TA Instruments (TGA Q50 V6.4 Build 193) employing $10 \mathrm{mg}$ of powdered sample packed into the platinum pan. The temperature range was $30-700{ }^{\circ} \mathrm{C}$ at a constant heating rate of $20^{\circ} \mathrm{C} \mathrm{min}{ }^{-1}$ under nitrogen atmosphere and a flow rate of $100 \mathrm{~mL} \mathrm{~min}^{-1} 7,8$. The determination of the total phosphorus of the phosphorylated copolymers was carried out by spectrophotometry using the molybdenum blue method ${ }^{9}$. Elemental analysis of the sulfophosphorylated copolymers was performed in a Vario Macro CHNS elemental analyzer and dynamic flash combustion was applied for sample analysis. FTIR spectra of the copolymers were obtained from $\mathrm{KBr}$ solid solution pellets by using a Perkin-Elmer (Spectrum One) spectrometer (4 scans and $4 \mathrm{~cm}^{-1}$ resolution).

\section{3) RESULTS AND DISCUSSION}

Sty-DVB copolymer with a macroporous structure was submitted to phosphorylation reaction by using $\mathrm{PCl}_{3} / \mathrm{AlCl}_{3}$ according to the method previously published ${ }^{5}$. Subsequently this copolymer was reacted with $\mathrm{CS}_{2}$ in order to introduce sulfophosphoryl groups onto poly- 
meric matrix. A scheme for the phosphoryation and sulfophosphorylation reactions is proposed in Scheme 1.

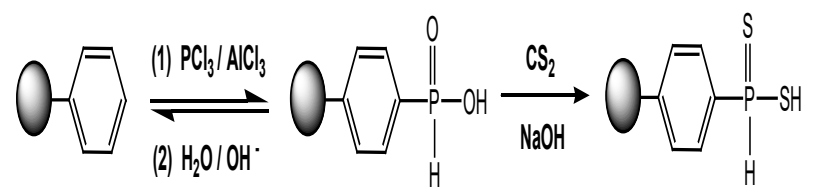

Figure 1: Phosphorylation reaction of StyDVB copolymer and reaction of phosphoryl groups with $\mathrm{CS}_{2}$ to generate sulfophosphoryl groups ${ }^{10}$.

The phosphorylation reaction was confirmed by bands at $2350 \mathrm{~cm}^{-1}$ due to $\mathrm{P}-\mathrm{H}$ stretching vibration, $1170 \mathrm{~cm}^{-1}$ due to $\mathrm{P}=\mathrm{O}$ stretching vibration, $991 \mathrm{~cm}^{-1}$ related to $\mathrm{P}-\mathrm{OH}$ stretching vibration and $1440 \mathrm{~cm}^{-1}$ due to bond P- $\mathrm{C}_{6} \mathrm{H}_{5}$, as well as by spectrophotometry using the molybdenum blue method (Table 1).

Table 1: Phosphorous content incorporated into Sty-DVB copolymers for reaction with $\mathrm{PCl}_{3} /$ $\mathrm{AlCl}_{3}$

\begin{tabular}{ccccc}
\hline Copolymer & $\begin{array}{c}\text { Temperature } \\
\left.{ }^{\circ} \mathrm{C}\right)\end{array}$ & $\mathrm{PCl}_{3}: \mathrm{ACl}_{3}$ & $\begin{array}{c}\mathrm{P}^{2} \\
(\mathrm{mmol} . \\
\left.\mathrm{g}^{-1}\right)\end{array}$ & $\begin{array}{c}\text { Phosphoryl } \\
\text { ation } \\
\text { degree (\%) }\end{array}$ \\
\hline PC1 & 85 & $1: 1$ & 3.29 & 55.68 \\
PC2 & 70 & $1: 1$ & 3.40 & 57.55 \\
PC3 & 60 & $1: 1$ & 3.75 & 63.47 \\
PC4 & 50 & $1: 1$ & 4.53 & 76.67 \\
PC5 & 25 & $1: 1$ & 4.51 & 76.33 \\
PC6 & 50 & $1: 1.2$ & 4.76 & 80.56 \\
PC7 & 50 & $1: 1.5$ & 5.08 & 85.97 \\
PC8 & 50 & $1: 2.0$ & 5.09 & 86.15 \\
PC9 & 50 & $1: 2.5$ & 5.10 & 86.32 \\
\hline
\end{tabular}

a Determined by spectrophotometry by using the molybdenum blue method ${ }^{9}$

Error $=0.01 \mathrm{mmol} . \mathrm{g}^{1}$ resin; reaction time: 15 $\mathrm{h}^{5}$

The sulfophosphorylation reaction was confirmed by the presence of three bands at 2540,
2349 and $649 \mathrm{~cm}^{-1}$, attributed to the $\mathrm{S}-\mathrm{H}$ stretching vibration, $\mathrm{P}-\mathrm{H}$ stretching vibration and $\mathrm{P}=\mathrm{S}$ vibration, respectively ${ }^{3}$, and by elemental analysis (Figure 2, Table 2).

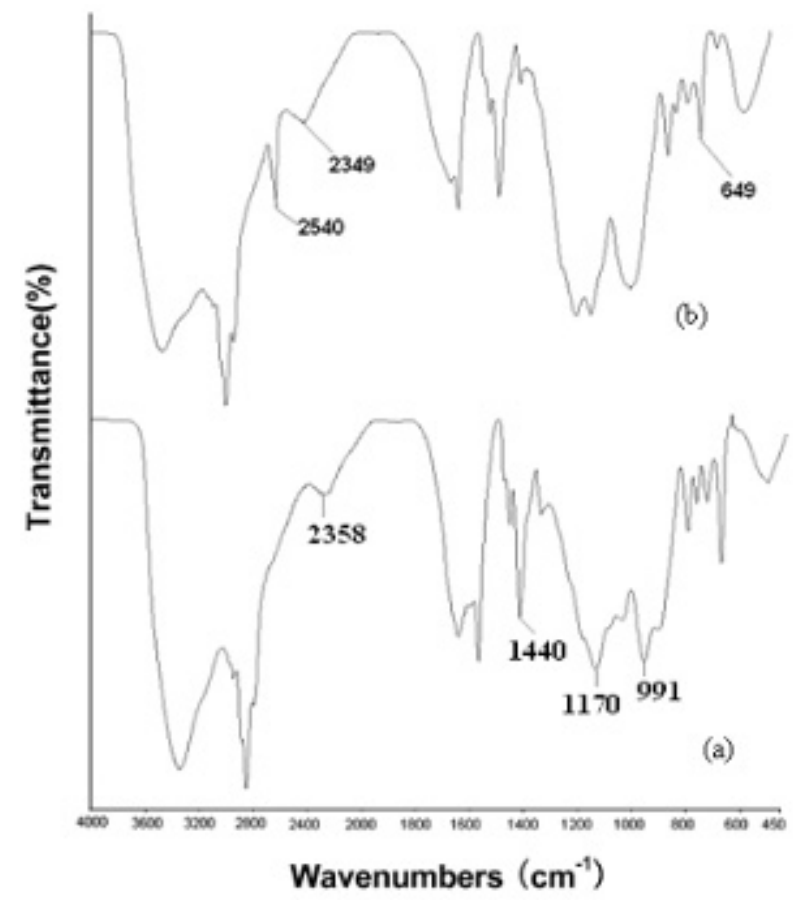

Figure 2: FTIR spectra of phosphorylated (a) and sulfophosphorylated (b) Sty-DVB copolymer

Table 2: Sulfur content incorporated into phosphorylated copolymers for reaction with $\mathrm{CS}_{2}$

\begin{tabular}{|c|c|c|c|c|}
\hline Copolymer & Time (h) & $\mathrm{CS} ;(\mathrm{mol})$ & $\mathrm{S}\left(\mathrm{mmol} \cdot \mathrm{g}^{\mathrm{N}}\right)^{2}$ & $\begin{array}{c}\text { Sulfoplosphorylation } \\
\text { degree (96) }\end{array}$ \\
\hline $\mathrm{SCl}$ & 24 & 0.013 & 0.07 & 1.41 \\
\hline $\mathrm{sc} 2$ & 24 & 0.026 & 0.15 & 2.92 \\
\hline $\mathrm{SC}_{3}$ & 24 & 0.039 & 0.14 & 2.81 \\
\hline $\mathrm{SC} 4$ & 24 & 0.250 & 0.47 & 9.45 \\
\hline scs & 72 & 0.013 & 0.10 & 2.01 \\
\hline sC6 & 72 & 0.026 & 0.14 & 2.87 \\
\hline sC7 & 72 & 0.039 & 0.16 & 3.22 \\
\hline $\mathrm{sc} 8$ & 72 & 0.250 & 0.47 & 9.45 \\
\hline SC9 & 144 & 0.013 & 0.44 & 8.85 \\
\hline $\mathrm{SC} 10$ & 144 & 0.026 & 0.38 & 7.64 \\
\hline SC11 & 144 & 0.039 & 0.38 & 7.64 \\
\hline $\mathrm{SC}_{12}$ & 144 & 0.250 & 0.48 & 9.65 \\
\hline
\end{tabular}

${ }^{\mathrm{a}}$ Determined by elemental analysis, Error $=0.02 \mathrm{mmol} . \mathrm{g}^{-1}$ The thermal stability of the Sty-DVB copolymer was significantly changed by the modification reactions (Figure 3). The unmodified copolymer by contain only thermally degradable organic material presented mass loss 
of $95.0 \%$, leaving $5.0 \%$ residue, and presented only one significant weight loss step at $409^{\circ} \mathrm{C}$ and a single DTG peak, related to the decomposition of the main chain of this copolymer at $442^{\circ} \mathrm{C}$ (Figure 3-a). Although the phosphorylated copolymer has presented only a single DTG peak at $477{ }^{\circ} \mathrm{C}$, the TG curve profile was different, indicating two weight loss stages. In addition, the degradation of this material left $35.7 \%$ residue (Figure 3-b). The displacement of the single DTG peak and the increase of the residue content confirm the presence of incorporated phosphorous (not thermally degradable). Phosphorous compounds are normally resistant to oxidation reactions ${ }^{2}$. Sulfophosphorylated copolymer presented a change in the DTG curve profile, attributed to the unfolding at $510{ }^{\circ} \mathrm{C}$ (Figure 3-c). This behavior was observed for all samples that presented high incorporated sulfur content. The incorporation of sulfur in phosphoryl groups caused a change in the degradation stage where the decomposition velocity of the polymeric chains is fastest.

Table 1 shows the results of phosphorous content and phosphorylation degree of the copolymers after phosphorylation reaction. This reaction was conducted by varying the molar ratio $\mathrm{PCl}_{3}: \mathrm{AlCl}_{3}$ and the reaction temperature.

It is possible to observe that the increase of the reaction temperature disfavors the phosphorylation reaction. The copolymer reacted at $85{ }^{\circ} \mathrm{C}$ presented phosphorylation degree of $55.68 \%$. This can be explained by the volatilization or hydrolysis of reactant $\mathrm{PCl}_{3}$.

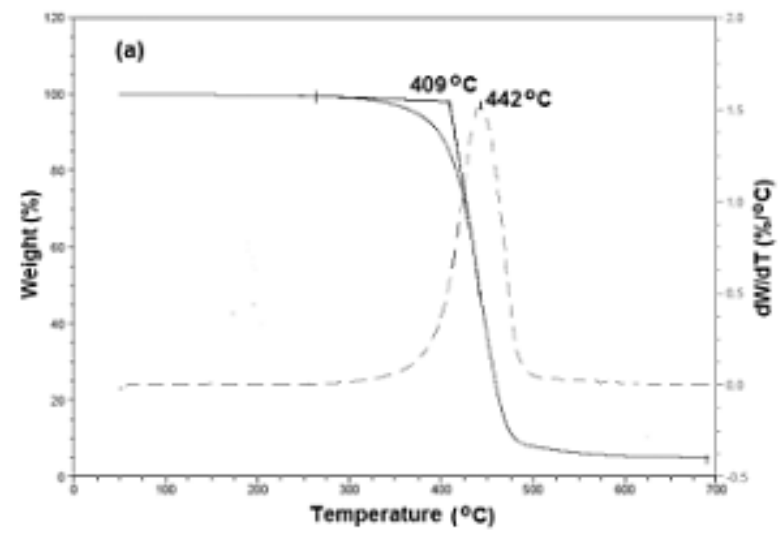

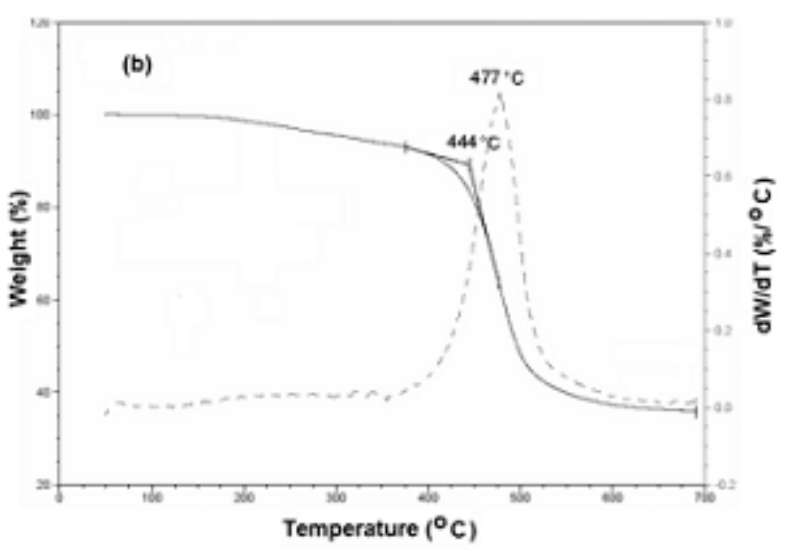

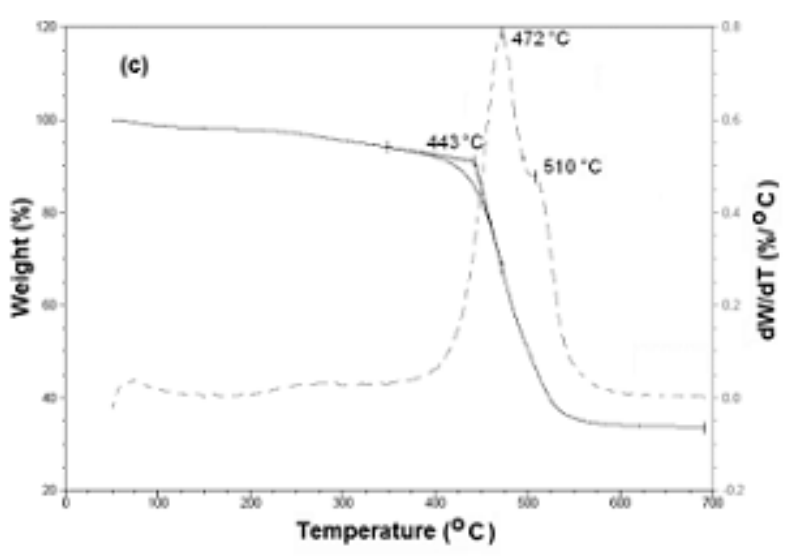

Figure 3: TG and DTG curves of the (a) Sty-DVB copolymer support (b) phosphorylated copolymer and (c) sulfophosphorylated copolymer

We also verified that the excessive increase of the amount of $\mathrm{AlCl}_{3}\left(\mathrm{PCl}_{3}: \mathrm{AlCl}_{3}<\right.$ 1/1.5) does not contribute to reaction, because electrophile formation $\left(\mathrm{PCl}_{2}^{+}\right)$is limited by $\mathrm{PCl}_{3}$ concentration (Scheme 1). We can say that the best conditions for phosphorylation reaction are: temperature $50{ }^{\circ} \mathrm{C}$ and molar ratio $\mathrm{PCl}_{3}: \mathrm{AlCl}_{3}=1: 1.5$ (copolymer PC7), once the copolymers PC8 and PC9 presented phosphorylation degree practically constant when compared to PC7.

Table 2 shows the sulfur content incorporated into phosphorylated copolymers after sulfophosphorylation reaction. This reaction was conducted by varying the reaction time and the amount of $\mathrm{CS}_{2}$ in relation to the phosphoryl group content.

As can be seen in Table 2, there is a tendency 
for increasing sulfur incorporation into the copolymers with the increase of the $\mathrm{CS}_{2}$ amount in the reaction mixture for the reaction times of 24 and $72 \mathrm{~h}$. However, for reaction times of 144 $h$ this effect is not pronounced. Several works have demonstrated that the reaction with carbon disulfide conduces to low conversion degrees and many of these works employ reaction times of $144 \mathrm{~h}$ (6 days) ${ }^{6,11}$. It is possible to suppose that this time is sufficient for that the reaction equilibrium is reached, in other words this reaction time is sufficient for that the saturation of the medium is perceived. Comparing the sulfophosphorylated copolymers pairs $\mathrm{SC} 1 / \mathrm{SC} 4$ and $\mathrm{SC} 5 /$ $\mathrm{SC} 8$, it is possible to observe that an increase of about 19 times in the CS2 proportion caused an increase of about 580 and $370 \%$ in the sulfur content, respectively (Table 2 ). With a reaction time of $144 \mathrm{~h}$, the amount of CS2 added did not significantly change the incorporated sulfur content. The FTIR spectra of these copolymers show that the bands at 2540, 2349 and $649 \mathrm{~cm}^{-}$ ${ }^{1}$, attributed to $\mathrm{S}-\mathrm{H}, \mathrm{P}-\mathrm{H}$ and $\mathrm{P}=\mathrm{S}$, respectively, are more intense for the copolymers $\mathrm{SC} 4$ and $\mathrm{SC} 8$, reacted with high amounts of $\mathrm{CS}_{2}$, confirming their higher content of sulfophosphoryl groups ${ }^{3,12}$ (Figure 4 - A and B). Analyzing the thermal decomposition temperatures $\left(\mathrm{T}_{\mathrm{dm}}\right)$ of the sulfophosphorylated copolymers (Table 3 ) it is possible to observe that the copolymers $\mathrm{SC} 4$ and $\mathrm{SC} 8$ presented a second degradation stage $\left(\mathrm{T}_{\mathrm{dm} 2}\right)$ when compared to copolymers SC5 and $\mathrm{SC} 8$, respectively. The unfolding $\left(\mathrm{T}_{\mathrm{dm} 2}\right)$ at $510.33{ }^{\circ} \mathrm{C}$ in the copolymer SC4 and at 509.87 ${ }^{\circ} \mathrm{C}$ in the copolymer SC8 (Figure 5) showed that these two materials incorporated more sulfur when compared to copolymers $\mathrm{SC} 1$ and $\mathrm{SC} 5$, respectively. In addition, the copolymers SC4, SC8 and SC12 (Figure 6), with addition of high amounts of CS2 $(0.25 \mathrm{~mol})$, showed two degradation stages due to high incorporation of sulfur into the polymeric matrix. It is also important to observe (Table 3) that the copolymers SC9, $\mathrm{SC} 10, \mathrm{SC} 11$ and $\mathrm{SC} 12$, with long reaction times (144 h), showed equally two degradation stages due to high incorporated sulfur contents.

Sulfophosphorylated copolymer SC12 showed the highest temperature onset $(436.890 \mathrm{C})$. It is due to this polymeric resin has presented higher sulfophosphorylation degree inducing the increase of the initial degradation temperature.

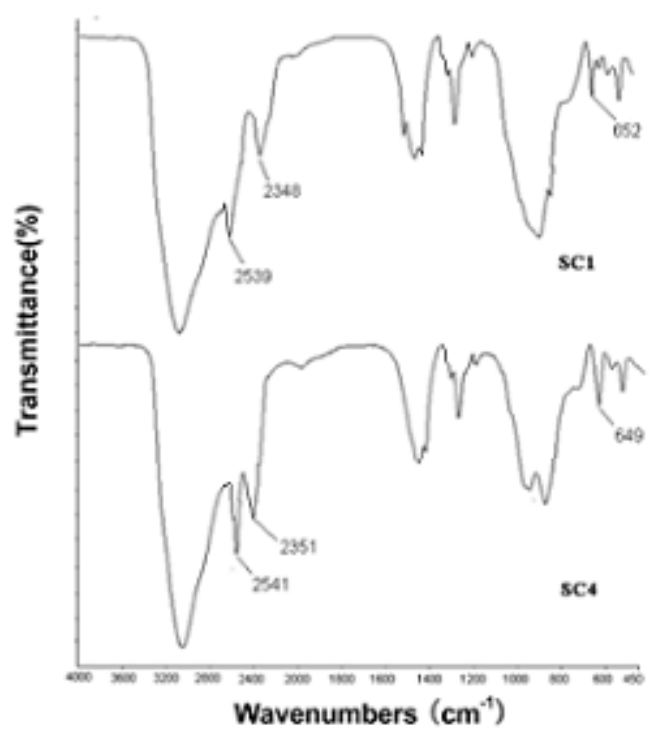

(A)

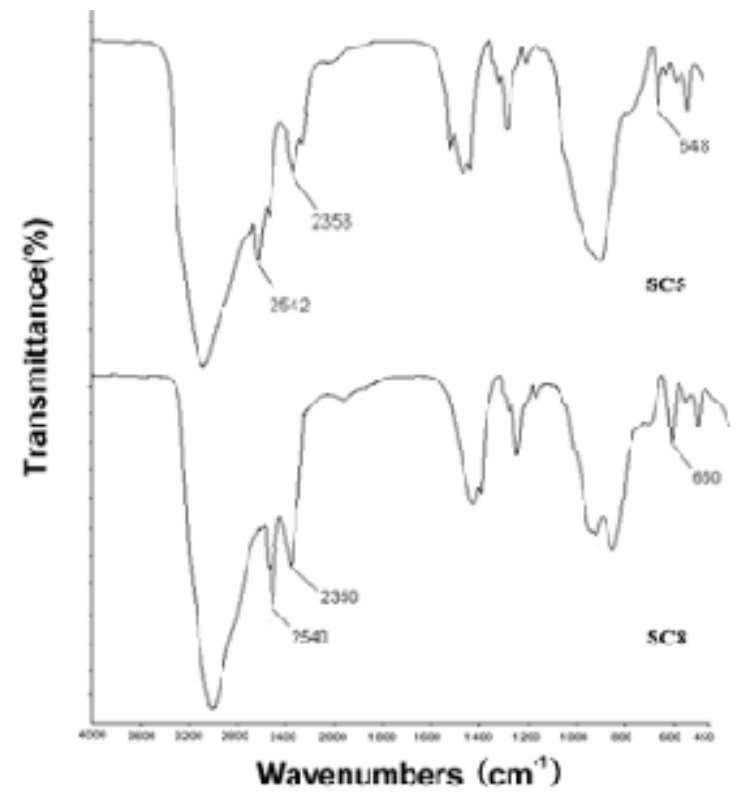

(B)

Figure 4: FTIR spectra of sulfophosphorylated copolymers SC1 and SC4 (A) and SC5 and $\mathrm{SC} 8(\mathrm{~B})$ 

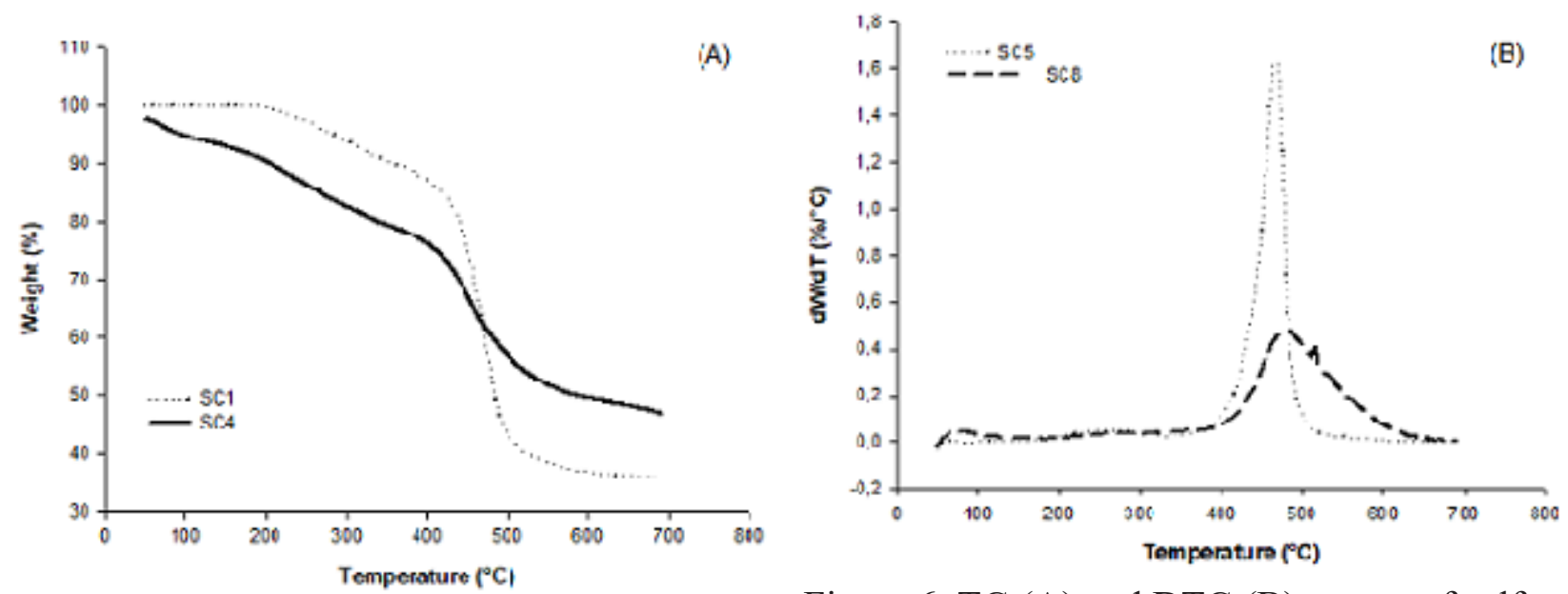

Figure 6: TG (A) and DTG (B) curves of sulfophosphorylated copolymers SC5 and SC8
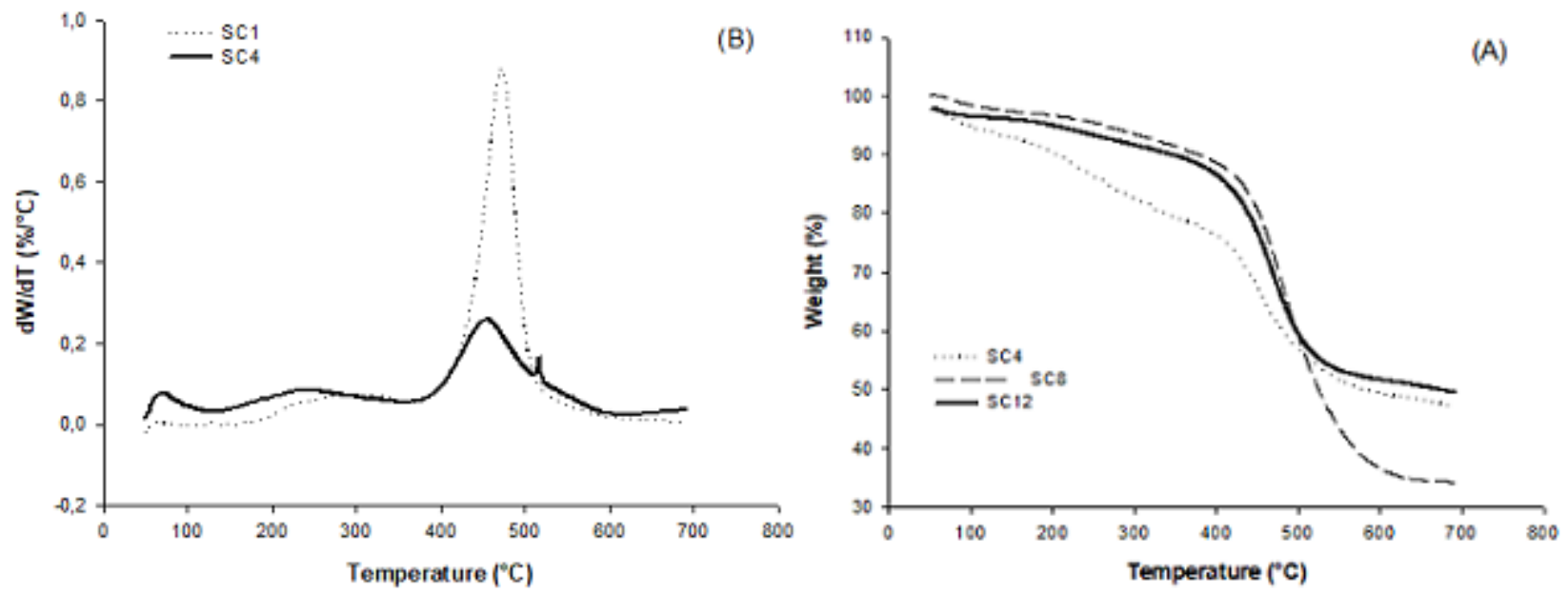

Figure 5: TG (A) and DTG (B) curves of sulfophosphorylated copolymers $\mathrm{SC} 1$ and $\mathrm{SC} 4$
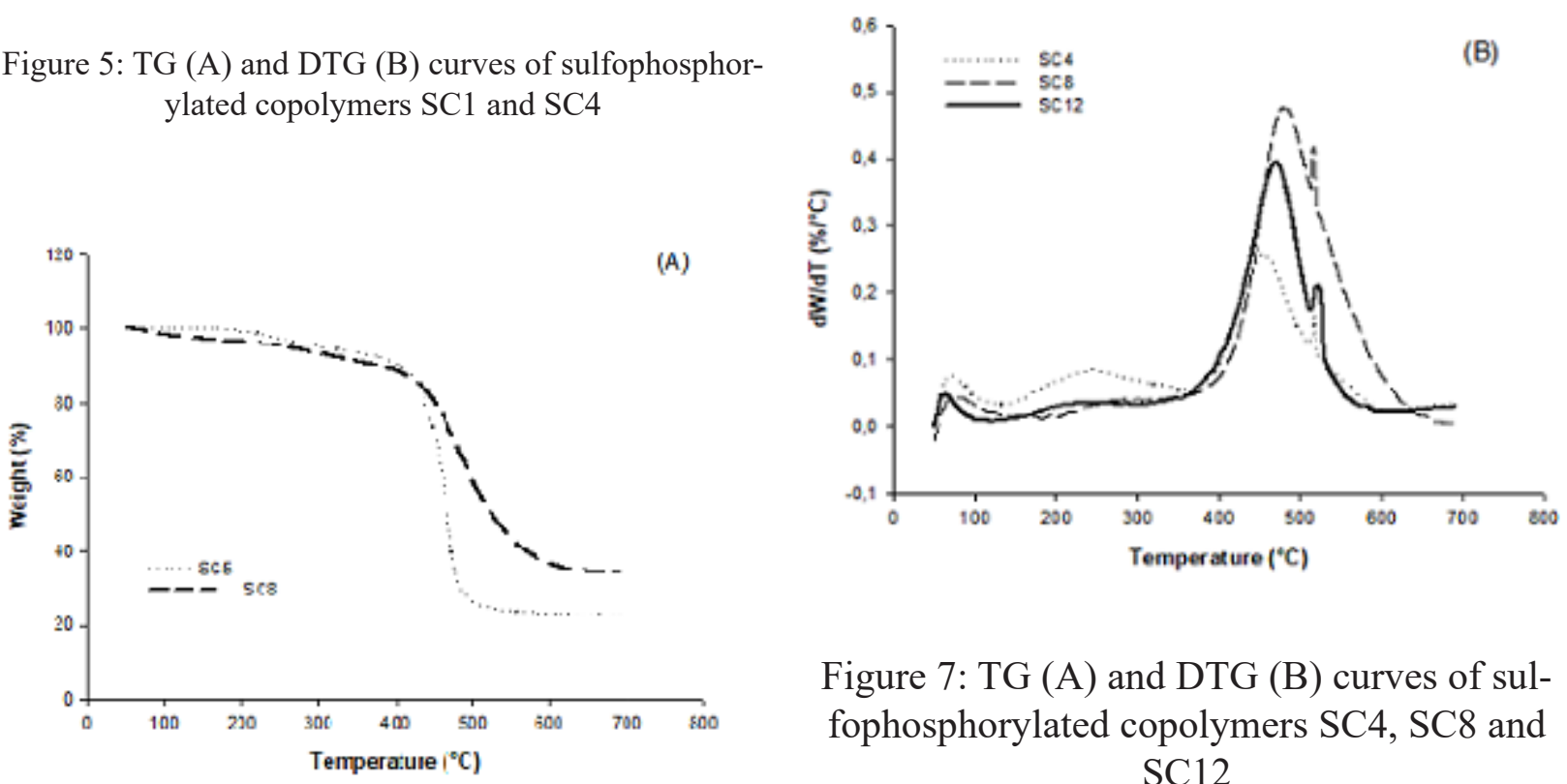

Figure 7: TG (A) and DTG (B) curves of sulfophosphorylated copolymers $\mathrm{SC} 4, \mathrm{SC} 8$ and $\mathrm{SC} 12$ 
Table 3: Thermal decomposition temperatures of the sulfophosphorylated copolymers

\begin{tabular}{|c|c|c|c|}
\hline Copolymer & $T \operatorname{sech}^{3}\left({ }^{\circ} \mathrm{C}\right)$ & $T=1^{b}\left({ }^{\circ} \mathrm{C}\right)$ & $\mathrm{T}_{\operatorname{dm} 2^{b}\left({ }^{\circ} \mathrm{C}\right)}$ \\
\hline $\mathrm{SCl}$ & 421.67 & 464.13 & $\cdot$ \\
\hline $\mathrm{SC} 2$ & 426.44 & 465.76 & - \\
\hline $\mathrm{SC} 3$ & 427.39 & 467.24 & - \\
\hline $\mathrm{SC} 4$ & 432.52 & 468.01 & 510.33 \\
\hline $\mathrm{sC5}$ & 428.29 & 455.89 & - \\
\hline SC6 & 429.92 & 463.89 & - \\
\hline $\mathrm{SC} 7$ & 430.67 & 469.99 & - \\
\hline SC8 & 433.22 & 481.91 & 509.87 \\
\hline SC9 & 430.93 & 477.23 & 510.95 \\
\hline $\mathrm{SC} 10$ & 431.78 & 475.39 & 508.23 \\
\hline $\mathrm{SC} 11$ & 432.11 & 476.19 & 509.56 \\
\hline $\mathrm{SC}_{12}$ & 436.89 & 478.87 & 511.01 \\
\hline
\end{tabular}

${ }^{\mathrm{a}}$ Initial temperature degradation; ${ }^{\mathrm{b}}$ Temperature where the degradation rate is maximal Error $=0.05^{\circ} \mathrm{C}$

Comparing the sulfophosphorylated copolymers $\mathrm{SC} 1 / \mathrm{SC} 5 / \mathrm{SC} 9, \mathrm{SC} 2 / \mathrm{SC} 6 / \mathrm{SC} 10$ and $\mathrm{SC} 3 / \mathrm{SC} 7 / \mathrm{SC} 11$ can be noted a tendency for increasing incorporation of sulfur with the increase of the reaction time (Table 2). This behavior is also confirmed by the FTIR spectra and TG/DTG curves of these materials, as can be seen in Figure 8 (FTIR spectra of SC1, SC5 and SC9 copolymers) and Figure 9 (TG/DTG curves of $\mathrm{SC} 1, \mathrm{SC} 5$ and $\mathrm{SC} 9$ copolymers). The bands at 2538, 2348 and $653 \mathrm{~cm}^{-1}$, attributed to $\mathrm{S}-\mathrm{H}, \mathrm{P}-\mathrm{H}$ and $\mathrm{P}=\mathrm{S}$, respectively, are more intense for the copolymer SC9 (Figure 8), reacted with longer reaction time (144 h), confirming higher content of sulfophosphoryl groups.

Sulfophosphorylated copolymer SC9 showed a change in the DTG curve profile attributed to the unfolding at $510.95^{\circ} \mathrm{C}$ (Figure 9). This behavior can be explained by the increase of the incorporation of sulfur when used long reaction times. When $0.25 \mathrm{~mol}$ of $\mathrm{CS}_{2}$ was used in the reaction mixture, the sulfur content incorporated into $\mathrm{SC} 4, \mathrm{SC} 8$ and $\mathrm{SC} 12$ copolymers for the three reaction times $(24,72$ and $144 \mathrm{~h})$ remained practically constant (Table 2 ). This behavior is also confirmed by the TG/DTG curves of SC4,
SC8 and SC12 copolymers (Figure 7). The DTG curves of these three copolymers present similar shifts, indicating the presence of the same amount of sulfophosphoryl groups in the copolymers. Thus, can be said that for high amounts of $\mathrm{CS}_{2}$ the reaction equilibrium is soon reached and the effect of the increase of the reaction time about the sulfur content is not perceived.

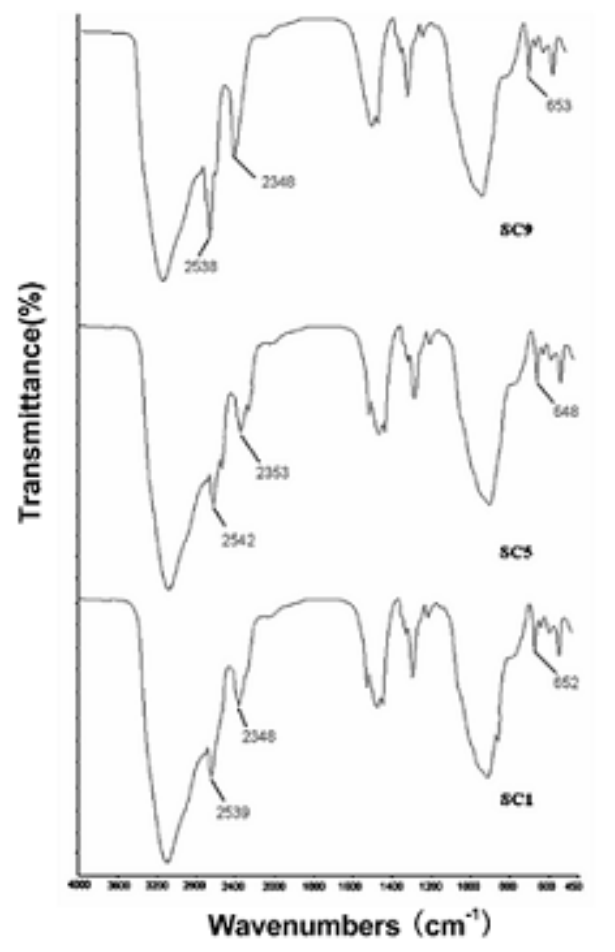

Figure 8: FTIR spectra of sulfophosphorylated copolymers SC1, SC5 and SC9

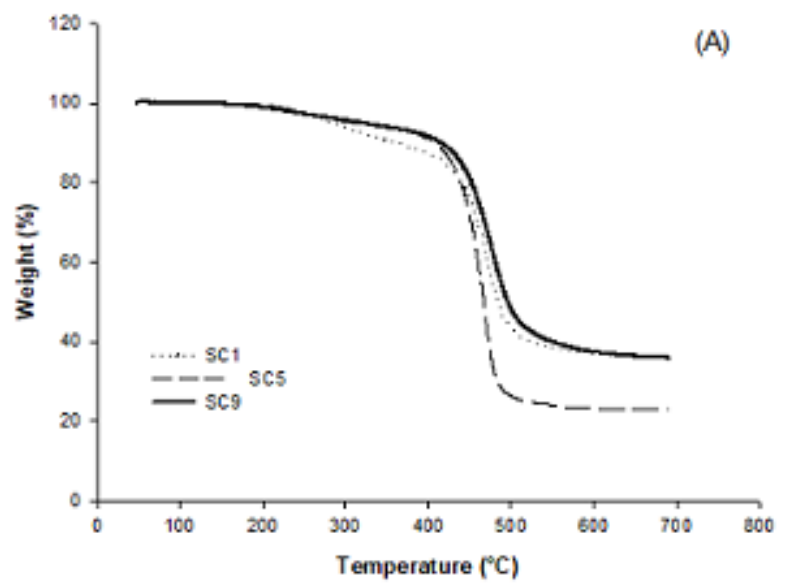


AS\&T Volume 6, Number 1, Jun 2018

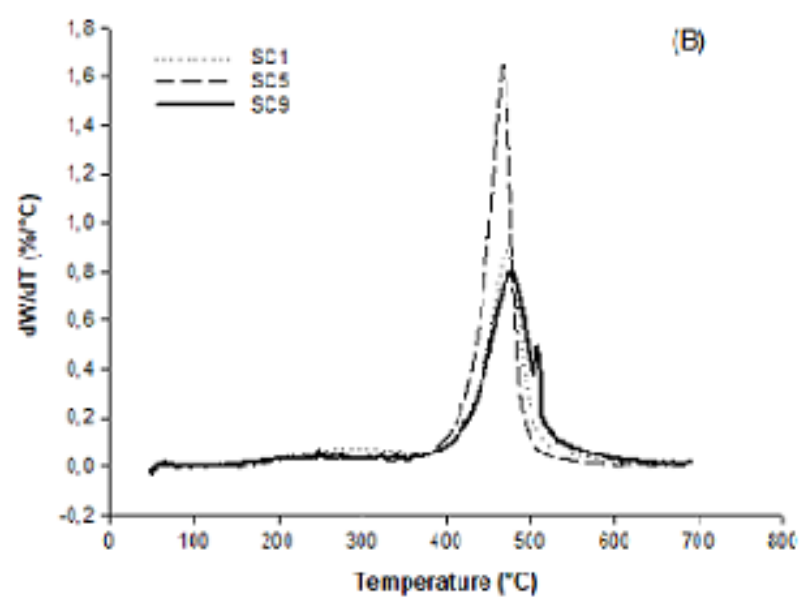

Figure 9: TG (A) and DTG (B) curves of sulfophosphorylated copolymers SC1, SC5 and SC9

\section{CONCLUSION}

The thermal stability and the FTIR spectra of the Sty-DVB copolymers were significantly changed after the phosphorylation and sulfophosphorylation reactions. There was a tendency for increasing content of sulfophosphoryl groups incorporated into Sty-DVB copolymers through the use higher amounts of CS2 and longer reaction times.

For high amounts of $\mathrm{CS}_{2}$, a long reaction time is not necessary to transform phosphoryl into sulfophosphoryl groups. The best conversion degree of phosphoryl into sulfophosphoryl groups was obtained by using reaction time of $144 \mathrm{~h}$ and $0.25 \mathrm{~mol}$ of $\mathrm{CS}_{2}$. The results of the optimization of the reaction parameters to transform phosphoryl into sulfophosphoryl groups will contribute to the achievement of efficient biocidal materials.

\section{5) ACKNOWLEDGEMENTS}

We are grateful for the financial support from CAPES and FAPERJ.

\section{REFERENCES}

1 ASHOK M, HOLLA B S. Convenient Synthesis of Some Thiadiazolotriazinones. 2007. Carrying 4-Methylthiobenzyl Moieties as Possible Antimicrobial Agents. Phosphorus Sulfur and Silicon and the Related Elements 182(5): 981-991.

\section{SANTOS V M R DONNICI C L COSTA} J B N CAIXEIRO J M R. 2007. Compostos organofosforados pentavalentes: histórico, métodos sintéticos de preparação e aplicações como inseticidas e agentes antitumorais. Química Nova 30(1): 159-170.

3 SOUZA M A V, SANTA MARIA L C, COSTA L C, GALVÃO R C, HUI W S, MERÇON F. 2012. Evaluation of the biocide activity of phosphorylated and sulfophosphorylated resins. Materials Letters 74, 121-124.

4 BONILLA A M, GARCÍA M F. 2012. Polymeric materials with antimicrobial activity. Progress in Polymer Science. 37: 281-339.

5 SOUZA M A V, SANTA MARIA L C, COSTA M A S, HUI W S, COSTA L C, ARAUJO FILHO H C. 2011. Synthesis, characterization and evaluation of phosphorylated resins in the removal of $\mathrm{Pb} 2+$ from aqueous solutions. Polymer Bulletin. 67: 237-249.

6 PRASUN K R, ASHOK S R, PRAMOD K R. 2003. Synthesis, characterization and evaluation of polydithiocarbamate resin supported on macroreticular styrene/divinylbenzene copolymer for the removal of trace and heavy metal ions. Talanta. 59: 239-246.

7 JANDREY A C, AGUIAR A P, AGUIAR M R M P, SANTA MARIA L C. 2004. Thermodegradation of poly(2-vinylpyridineco-styrene-co-divinylbenzene) and $\mathrm{N}$-oxide derivatives. Thermochimica Acta. 424: 63-68. 
8 RIQUEZA E C, AGUIAR A P, AGUIAR M R M P, SANTA MARIA L C. 2007. Thermogravimetric study of some crosslinked copolymers based on poly(acrylonitrile-codivinylbenzene). Thermochimica Acta, 456(2): 128-133.

9 CROUCH S R, MALMSTADT H V. 1967. Mechanistic investigation of molybdenum blue method for determination of phosphate. Analytical Chemistry 39(10): 1084-1089. 10 SOUZA M A V. Tese de Doutorado, Universidade do Estado do Rio de Janeiro, 2012.

11 COSTA P A D, TEIXEIRA V G. 2010. Influence of the Matrix Porosity on the Synthesis and Adsorption Behavior of Dithiocarbamate Styrenic Resins Toward Zinc(II) and Cadmium(II) Ions. Journal of Applied Polymer Science116: 3070-3078.

12 COLTHUP N B, DALY L H, WIBERLEY S E.1964. Introduction to Infrared and Raman Spectroscopy, Academic Press Inc., New York and London, 1964. 